\title{
Investigating the leading drivers of organic farming: A survival analysis
}

\author{
Muhammad Waqar Akram ${ }^{1,2^{*}}$ (i) Nida Akram ${ }^{1}$ Wang hongshu $^{1^{*}}$ Shahla Andleeb $^{3}$ \\ Khalil ur Rehman ${ }^{3}$ Farhaan Hassan $^{4}$
}

${ }^{1}$ College of Economics \& Management, North East Forestry University, Harbin 150040, China. E-mail: waqar.akram13@yahoo.com. ${ }^{*}$ Corresponding author.

${ }^{2}$ Department of Business Administration, Ilma University, Main Ibrahim Hyderi Road, Korangi Creek, Karachi 75190, Pakistan.

${ }^{3}$ Government College Women University, Sialkot, Punjab, Pakistan.

${ }^{4}$ Allama Iqbal Open University Islamabad, Pakistan.

ABSTRACT: This research evaluated farmers'decisions to adopt organic farming. It was first introduced by developed countries to minimize environmental impacts originated by intensive use of synthetic fertilizers and pesticides to enhance production yield. Although, organic farming offers environmentally sound methodologies for crop production, but Asian farmers are reluctant to adopt organic farming. In this study, a survival analysis (SA) was employed to determine the reasons for and the time is taken by farmers to adopt organic agriculture. This research studied the farmers' goals, agricultural policies, and attitude towards risk, as covariates in the survival analysis. A multiple criteria decisionmaking method based on the Analytic Hierarchy Process was used to evaluate the farmers'goals. Data were collected from agricultural farms located in three districts in Punjab, Pakistan. A questionnaire was used to collect empirical evidence. This study reported that the farmers' goals were crucial to their acceptance of organic farming; furthermore, young farmers and farmers with risk-inclined attitudes were more prone to adopting organic farming. The study also determined that change in policy and introduce special package for organic agriculture can encouraged the adoption of organic methods.

Key words: farming method, organic farming, yield, farmer attitude, survival analysis.

Investigando as principais formas de impulsionar a agricultura orgânica:

uma análise de sobrevivência

RESUMO: $O$ objetivo do presente estudo é avaliar as decisões dos agricultores de adotar a agricultura orgânica. Foi introduzido pela primeira vez por países desenvolvidos para minimizar os impactos ambientais originados pelo uso intensivo de fertilizantes sintéticos e pesticidas para aumentar o rendimento da produção. Embora a agricultura orgânica ofereça metodologias ambientalmente corretas para a produção agrícola, os agricultores asiáticos relutam em adotar a agricultura orgânica. Neste estudo, uma análise de sobrevivência (SA) foi empregada para determinar os motivos e o tempo que os agricultores levam para adotar a agricultura orgânica. Esta pesquisa estudou os objetivos dos agricultores, as políticas agrícolas e a atitude em relação ao risco, como covariáveis na análise de sobrevivência. Um método de tomada de decisão de múltiplos critérios com base no Processo de Hierarquia Analítica foi usado para avaliar os objetivos dos agricultores. Os dados foram coletados em fazendas agrícolas localizadas em três distritos de Punjab, Paquistão. Um questionário foi usado para coletar evidências empíricas. Este estudo descobriu que os objetivos dos agricultores eram cruciais para aceitação da agricultura orgânica; além disso, jovens agricultores e agricultores com atitudes inclinadas a risco eram mais propensos a adotar a agricultura orgânica. $O$ estudo também determinou que a mudança na política e a introdução de um pacote especial para a agricultura orgânica podem estimular a adoção de métodos orgânicos.

Palavras-chave: método de cultivo, agricultura orgânica, produção, atitude do agricultor, análise de sobrevivência.

\section{INTRODUCTION}

Organic agriculture has become a hot issue in debates linked with environmental protection, health foods, sustainable natural resources, and social welfare. The rapid growth of the world population has threatened food availability (BURTON et al., 2003). To cope with this problem, farmers were using external inputs such as fertilizer and pesticides to increase crop yield (GODFRAY et al., 2010). These inputs hurt human health, besides damaging the environment and the entire ecosystem(AUERBACH, 2013); that's why public authorities were encouraging farmers to take up environmentally friendly practices, one of which was organic agriculture (ABDULAI \& HUFFMAN, 2005). Organic agriculture relied on

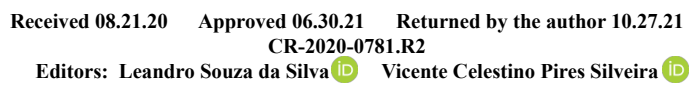


agronomic, biological, and other natural resources that could not harm local conditions or needs (BAKER $\&$ MOHLER, 2015). So, trend of organic agriculture adoption has been increasing continuously since past few years. Countries in Oceania (Australia, New Zealand, Pacific island groups) have 17.3 million hectares of land and are currently the world leaders in organic agriculture, contributing to $40 \%$ of world organic production (DADI et al., 2004). This was followed by Europe, America (Latin America, North America, \& The Caribbean), Asia, and Africa, each with 11.6, 9.8, 3.6, and 1.3 million hectares of land and contributing $27 \%, 22 \%, 8 \%$, and $3 \%$ of world organic production, respectively (WILLER \& LERNOUD, 2016). Pakistan was also considering adopting organic agriculture because of its environmentally sound results (DE SOUZA FILHO et al., 1999). First it was able to reduce the pressure on import of farm inputs and can also export organic product more specifically China via China Pakistan economic corridor (CPEC) (AKRAM et al., 2019b). Secondly government wanted to tackle the human health, soil degradation and environment challenges through organic farming (AKRAM et al., 2019a). For this reason, country established a Directorate of Organic Farming in 2008 to facilitate small-scale farmers and improve organic farming. Later, the Directorate has renamed the National Institute of Organic Agriculture with a new scope that included training farmers, applying new technologies, using bio fertilizers and bio pesticides, and increasing awareness of organic farming (KIEFER, 1988; LANCASTER, 1992). The rapid growth of organic farming has been evident for quite a while. Even after ten years of organic farming in Pakistan, the rate of adoption was still shallow compared to its neighbouring countries (AKRAM et al., 2020). The total area of organic agriculture in Pakistan was 51304 ha in 2017, which made up only $0.1 \%$ of the total agricultural land in Pakistan. Although, this area was $11.7 \%$ more than last year, and launched a system that registers organic farming practices used by traders and organic farmers, and hitherto, more than 5,000 farmers and agricultural students have been trained in organic farming practices (http://www.parc.gov.pk/index. php/en/nioa-achievements) but was still lower than its potential (WILLER \& LERNOUD, 2019).

Different studies investigated different parameters to adopt organic farming (FEDER \& UMALI, 1993; GARDEBROEK, 2006). In general, previous studies on adoption attitude have neglected considering the implementation time period of organic agriculture and the effect of time-sensitive elements
(RIGBY et al., 2001; DE COCK, 2005; GENIUS et al., 2006; ISIN et al., 2007; MZOUGHI, 2011). In addition, the diffusion approach did not consider the question of why a farmer would adopt organic farming before other farmers (BURTON et al., 2003). An alternative technique called survival analysis (SA) could be used to investigate the diffusion aspect and decision-making aspects inorganic agriculture adoption (KNOLL et al., 2018). This method broke down cross-sectional and time-variation information mutually in a dynamic structure (MCWILLIAMS \& ZILBERMANFR, 1996). SA allowed the researchers to determine why farmers embraced organic agriculture, the time limit to embrace this type of agriculture, and the variables that caused impact on perceived time variables.SA has taken into account the deviation in explanatory variables between time and farmer; and therefore, enabled the collective study of diffusion and adoption (SGROI et al., 2015; MEIER et al., 2015; REGANOLD \& WACHTER, 2016; SCHRAMA et al., 2018; FROEHLICH et al., 2018).

This examined the adoption of organic farming in Pakistan using the SA approach. The main aim of the study was to evaluate the impact of farmer's attributes, views, and attitude, cultivation arrangement, outputs, and efficiency of farm supervision, and different external variables on organic farming adoption. This study will add to the body of knowledge in this field by employing a SA analysis to prove that farmers' goals are a significant aspect of explaining conversion decisions. It explored the influence of farmer's approach and opinion on the adoption of organic agriculture and presents the farmers' preferences of risk in one model. In addition, the effect of organic policy during the adoption period is also examined. Another input of this paper is the consideration of a random control function, which described the adoption of all organic farm data that has never been considered previously. Comprehensively, this study is a new addition to the rare literature on organic adoption duration and, more specifically, focuses on a lesser-studied country, Pakistan.

The rest of this article is ordered as follows: Part 2 explains the influential factors impacting organic farming adoption; Parts 3 and 4 present the theoretical framework and empirical application, respectively; and Part 5 presents the results and defines the conclusion of the study.

Factors that lead to the adoption of organic farming

Several articles have been published on variables that affect organic farming adoption (PADEL \& LAMPKIN, 1994; RIGBY et al., 2001; KNOWLER

Ciência Rural, v.52, n.7, 2022. 
\& BRADSHAW, 2007). Some emphasized on the modification of organic farming (RIGBY et al., 2001; ULLAH et al., 2015; FROEHLICH et al., 2018). Conversely, this study introduced new dimensions of organic farming by reviewing the latest studies, their application of methods, and target populations (Table 1). The most important variables that may affect the adoption decisions of farmers towards organic or conventional agriculture were determined by reviewing the prior literature according to the guidelines below:
Farmer' personal attributes: age, gender, marital status, education, etc.

Structural management of farm: size of farm, location, fertility, farm mechanization, etc.

Operational management of farm: irrigation source, crop rotation, use of inputs, etc.

External variables: information source, size of market, government policies, subsidies, input cost, output prices, conversion cost, etc.

Farmer's opinion and approach: farmer's approach towards the environment, lifestyle,

Table 1 - Review of Previous studies.

\begin{tabular}{|c|c|c|c|}
\hline Method of Analysis & Sample Size & Region & Study \\
\hline Bayesian Logistic Growth Model & 16 & The Netherlands & $\begin{array}{l}\text { Gardebroek and Jongeneel } \\
\qquad(2004)\end{array}$ \\
\hline Bayesian Spatial Durbin Probit Model & 600 & Ireland & Läpple and Kelley (2014) \\
\hline Binary Choice Model & $\mathrm{CF}=388 \mathrm{OF}=143$ & Czech Republic & Mala and Maly (2013) \\
\hline Binary Logistic Regression & 100 & Pakistan & Ullah et al. (2015) \\
\hline Decision Tree Modeling & $\mathrm{CF}=12 \mathrm{OF}=9$ & Austria & Darnhofer et al. (2005) \\
\hline Dynamic Linear Programming & & Denmark & Acs et al. (2007) \\
\hline Endogenous Switching Regression Model & 386 & Ghana & Kleemann et al. (2014) \\
\hline Empirical Switching Regression Model & 247 & USA & Kuminoff and Wossink (2010) \\
\hline Focus group & 61 & USA & Hanson et al. (2004) \\
\hline Linear programming simulations & 685 & Belgium & Kerselaers et al. (2007) \\
\hline Investment under uncertainty & & Germany and Austria & $\begin{array}{l}\text { Musshoff and Hirschauer } \\
\qquad(2008)\end{array}$ \\
\hline Logit Regression Model & $\mathrm{CF}=45 \mathrm{OF}=150$ & Bangladesh & Sarker et al. (2009) \\
\hline $\begin{array}{l}\text { Logistic Regression } \\
\text { Analysis }\end{array}$ & 172 & Thailand & $\begin{array}{l}\text { Thapa and Rattanasuteerakul } \\
\text { (2011) }\end{array}$ \\
\hline Multi-disciplinary approach(chi-square test) & $\mathrm{OF}=29$ & South Africa & $\begin{array}{l}\text { (Niemeyer and Lombard, } \\
\text { 2003)) }\end{array}$ \\
\hline Multinomial Logit Regression & $\begin{array}{c}\mathrm{CF}=134 \mathrm{OF}=38 \\
\mathrm{IP}=71\end{array}$ & France & Mzoughi (2011) \\
\hline Multinomial Logit Regression & $\mathrm{CF}=118 \mathrm{OF}=28$ & USA & Anderson et al. (2005) \\
\hline Multinomial Logit Regression & $\mathrm{CF}=696 \mathrm{OF}=284$ & Norway & Koesling et al. (2008) \\
\hline Multiple regression analysis & $\mathrm{OF}=65$ & Nepal & Kafle (2011) \\
\hline Option Theory & $\mathrm{CF}=167 \mathrm{OF}=80$ & USA & Kuminoff and Wossink (2005) \\
\hline Ordered Probit Model & $\begin{array}{c}\mathrm{CF}=118 \mathrm{OF}=44 \\
\mathrm{PF}=75\end{array}$ & Greece & Genius et al. (2006) \\
\hline Ordered Probit Model & 254 & Spain & $\begin{array}{l}\text { Calatrava-Requena and } \\
\text { González (2008) }\end{array}$ \\
\hline Probit Model & $\mathrm{CF}=107 \mathrm{OF}=20$ & Turkey & Isin et al. (2007) \\
\hline Theory of Planned Behavior & $\mathrm{CF}=4593 \mathrm{OF}=230$ & Latvia and Estonia & Kaufmann et al. (2009) \\
\hline
\end{tabular}

Ciência Rural, v.52, n.7, 2022. 
recognition from rural society, environmental and health hazards, etc.

The variables studied in this research are listed in table 2. These have been commonly used to explain the adoption of organic agriculture and their impact on adoption decision. Highly educated young women have a higher tendency to adopt organic farming. Conversely, more seasoned farmers with important informal organizations are less inclined to adopt organic farming. Family farms have more tendencies to convert, including farmers with their own land, farmers with an easy source of irrigation, and farmers with fertile soil. A farmer's personal attributes may also affect his or her conversion to organic farming. Besides, farmers that are well aware of environmental issues, healthy food, and the degradation of soil, are also more likely to adopt organic farming. Moreover, these kinds of farmers are well informed about economic variables and new trends in farming, such as the use of electronic gadgets, including smartphones, the Internet, etc. This study also explained the vital role of government policies, subsidies, and the premium price of organic products as influential variables in organic farming adoption

\section{MATERIALS AND METHODS}

According to the literature review conducted in this study, five categories of factors affected the decision to adopt organic farming. These categories were the farmer's personal attributes, the structural management of the farm, the operational management of the farm, external variables, and the farmer's opinion and approach. The farmer's goals and intentions were also considered as a new addition to the previous literature, specifically in Pakistan. Therefore, this study employed Principal Component Analysis (PCA) used to summarize the farmers' opinion and approach and group them into components while AHP was employed to evaluate the goal and intentions of the farmer as a multi-condition decision-making method to evaluate farmers' goals, to which the study proved that these measures area standard variable of survival analysis (SA).

\section{The analytic hierarchy process $(A H P)$}

As stated earlier, it was assumed that the farmer's goal could be a vital element in the decision to adopt organic farming(DE COCK, 2005). However, collecting data about the overall significance of each farmer's goals was complex. A previous research explained that AHP offered multi-criteria decisionmaking in specific situations (SAATY, 1977). To assist in decision-making, AHP allowed the researcher to evaluate every goal of the farmer. As part of the AHP analysis, a survey was conducted among farmers who were asked to rate different goals on a scale according to their priorities, as shown in figure 1 . The main goal was then categorized into three groups, which included financial, environmental, and social. Then, each category was further split into three sub-categories.

The goal's weight or comparative significance was obtained from conducting a matching assessment. To make these assessments and to decide

Table 2 - Impact of different variables on the decision to adopt organic farming.

\begin{tabular}{|c|c|c|c|}
\hline Variable & Impact direction & Variable & Impact direction \\
\hline Education & Positive & Risk-averse & Negative \\
\hline Age & Negative & Farming experience & Negative \\
\hline Farm size & Negative & Farmer lives in an urban area & Positive \\
\hline Other economic activity & Positive & Home to farm distance & Negative \\
\hline Attitude towards conversion & Positive & Soil analysis & Positive \\
\hline Consideration of degradation of soil & Positive & Use of information technology & Positive \\
\hline Irrigation facility & Positive & Neighbor Organic farm & Positive \\
\hline Soil fertility & Positive & Agriculture conference & Positive \\
\hline Family labor & Positive & Concern for human health & Positive \\
\hline Hired labor & Positive & Government Or external support & Positive \\
\hline Information source & Positive & Access to credit & Negative \\
\hline Protection of the environment & Positive & Food safety & Positive \\
\hline Farmer organization & Positive & Social contact & Negative \\
\hline
\end{tabular}

Ciência Rural, v.52, n.7, 2022. 


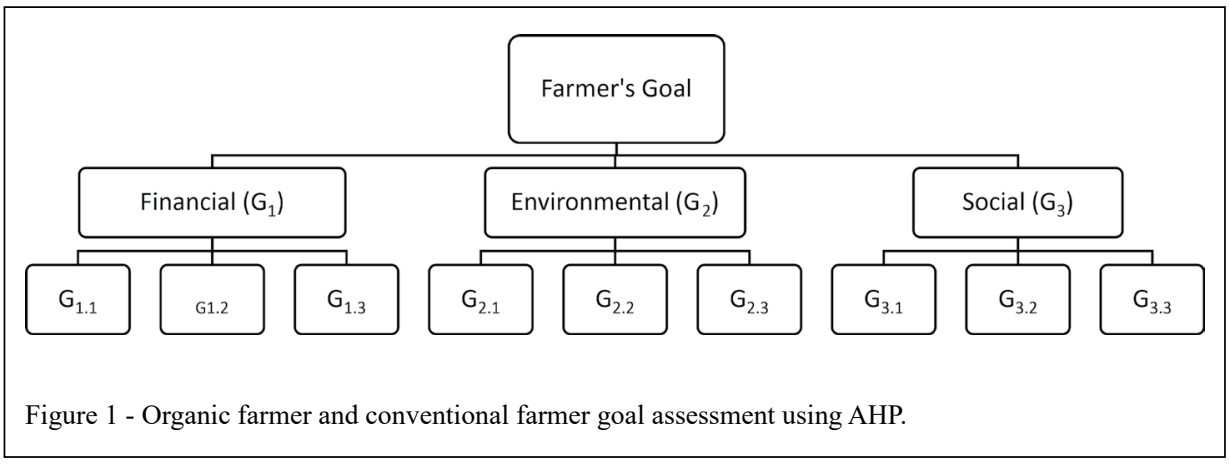

the significance of inclinations for every choice, a scale of 1 to 9 was used (SAATY, 1980). By comparing each goal to all other goals, the comparative significance of each goal was attained with the help of the matrix in Equation (1) for each farmer $(k)$.

$A_{k}=\left[\begin{array}{cccc}a_{11 k} & a_{12 k} & \ldots . & a_{1 n k} \\ a_{21 k} & a_{22 k} & \ldots . & a_{2 n k} \\ \ldots . & \ldots & a_{i i k} & \ldots . \\ a_{n 1 k} & a_{n 2 k} & \ldots . & a_{n n k}\end{array}\right]$

Where $a_{i j k}$ denoted the output of every individual by comparing goal $(i)$ with a goal $(j)$. The two basic characteristics of the square matrix were: i) the main diagonal value was taken as one $\left(a_{i j k}=1\right.$ $\forall i$ ) for all factors, and (ii) all other factors confirm the reciprocal paired assessment (If $a_{i j k}=x$ then $a_{j i k}$ $=\frac{1}{x}$ ). If the preferences of each decision-maker were precisely the same, then, it must also be confirmed that $\mathrm{a}_{\mathrm{ihk}} \times \mathrm{a}_{\mathrm{hjk}}=\mathrm{a}_{\mathrm{ijk}}$ for all, $i, j$, and $h$. This statement indicated that the value was assumed to be a relevant comparison when the weight specified to each goal was done using a fully coherent decision maker $\mathrm{a}_{\mathrm{ijk}}=$ $\mathrm{w}_{\mathrm{ik}} / \mathrm{w}_{\mathrm{jk}}$ for each $i$ and $j$. Therefore, this matrix could be rewritten as the matrix in Equation (2):

$$
A_{k}=\left[\begin{array}{cccc}
\frac{w_{1 k}}{w_{1 k}} & \frac{w_{1 k}}{w_{2 k}} & \ldots & \frac{w_{1 k}}{w_{n k}} \\
\frac{w_{2 k}}{w_{2 k}} & \frac{w_{2 k}}{w_{2 k}} & \ldots & \frac{w_{2 k}}{w_{n k}} \\
\ldots & \ldots & \frac{w_{i k}}{w_{j k}} & \ldots . \\
\frac{w_{n k}}{w_{1 k}} & \frac{w_{n k}}{w_{2 k}} & \ldots & \frac{w_{n k}}{w_{n k}}
\end{array}\right]
$$

Therefore, if the decision-makers' assets of impeccable dependability hold, the $n$ weight $w_{i k}$ for every goal could effectively be decided from the value $n(n-1) / 2$ for $a_{i j k}$. Disappointingly, impeccable dependability, it was very rare, where individual subjectivity assumes an essential part in assessing the paired evaluation. There was a little bit of undependability existing in the matrix $\left(\mathrm{A}_{\mathrm{k}}\right.$ $=\mathrm{a}_{\mathrm{ijk}}$ ), so another method was suggested to evaluate the weight vector closest to the real weight vector of the decision-maker. The two kinds of possibilities were the main eigenvector and the geometric mean, which Saaty (1980; 2003) also recommended for closely evaluating real weight. Different authors recommended alternative methods as well; LAININEN \& HÄMÄLÄINEN (2003) recommended regression-based analysis while another study recommended the goal program (BRYSON et al., 1995). However, there was still no consensus as to which method was better (FICHTNER, 1986). Since all standards met the above weight estimation requirements, this study adopted the geometric mean method (AGUARÓN \& MORENO-JIMÉNEZ, 2000; BAUMANN et al., 2007). Using this method, assigning a weight for every goal of the farmer was done as per Equation (3):

$$
w_{i k}=\sqrt[n]{\Pi_{i=1}^{i=n}} a_{i j k} \forall i
$$

Here, the $w_{i k}$ variable was utilized in the SA analysis as a covariate. AHP was initially considered for personal decision making. However, it was quickly stretched into an effective way of examining group decisions (EASLEY et al., 2000).In order to compare the weights of goals among conventional and organic farmers, the preferences of the group should be considered. Therefore, the corresponding weight of each farmer $\left(w_{i k}\right)$ among the farmers was obtained to get the weight combination for each goal $\left(w_{i}\right)$. The accumulation method should take place by a previous study (FORMAN \& PENIWATI, 1998), which stated that the most appropriate way to evaluate personal weights $\left(w_{i k}\right)$ in the context of collective social decisionmaking is the geometric mean, where the AHP analysis output is summarized using $w_{i}$, as given by Equation (4):

$w_{i}=\sqrt[m]{\Pi_{k=1}^{k=m}} w_{i k} \forall i$

\section{Survival Analysis (SA)}

Survival analysis was also known as duration modelling or duration analysis in the field 
of economics, which included the length of time of a session or the time period of a scene or the duration for an event to happen. The session begins at the entrance into a state and ended at a moment when the new state arrives. As stated above, SA was applied to determine the adoption factors of organic farming in addition to the time $(t)$ likelihood of a farm to adopt the organic approach because they do usually not adopt the method at a specific time. It was expected that the end of an occasion or the act of going into another state will occur only once for each individual (When an incident occurs multiple times, a multilevel model for frequent or repeat incidents should be applied (for more detail, see (Box-Steffensmeier and Zorn, 2002; Steele, 2008)).

The Theory of Probability was a foundation of the SA analysis. The Theory could focus on the probability of the ending or the probability of turning into another state instead of focusing on the time period of a session. A hazard function was utilized in the SA analysis in place of the probability distribution estimation in order to determine probability.

Suppose a random variable to evaluate the span of the session was denoted as $(T)$ and similarly suppose $(t)$ was an insight of $(T)$. Therefore, the time span observed for everyone comprises a series of data $\left(t_{1}, t_{2}, \ldots t_{n}\right)$. So, the function $f(t)$, as per Equation (5), must be continuous probability distribution estimation (PDE) of the earlier specified random variable $T$. The cumulative density estimation (CDE) was used to determine the probability distribution of the time period variable.

$$
F(t)=\int_{0}^{t} f(s) d s=\operatorname{Pr}(T \leq t)
$$

It was demonstrated that the specific value was bigger than the probability of the random variable $(T)$. However, the study was more interested in determining the probability of the length of the time span $(t)$ for the survival analysis. The paired cumulative distribution estimation (PCDE), also known as survivor estimation, assesses this probability, and this was given by Equation (6):

$S(t)=1-F(t)=\int_{t}^{\infty} f(s) d s=\operatorname{Pr}(T>t)$

The session begins at the entrance into a state and ended at a moment when the new state arrived.

Considering the probability that the spell lasts until, where closures or changing to a new state within a short duration of time was given by Equation (7):

$\operatorname{Pr}(t \leq T<t+\Delta t \mid T \geq t)$

The hazard function was determined based on this probability or the degree of the hazard, which determines the rate at the time $T=t$ by which a period was finished, which specified that it survived up to time $t$. It was meant that the adoption probability of organic methods at a time was signified by the hazard function because it was not adopted before $t$. This hazard function was given by Equation (8):

$$
\begin{aligned}
& h(t)=\lim _{\Delta t \rightarrow 0} \frac{\operatorname{Pr}(t \leq T<t+\Delta t \mid T \geqq t)}{\Delta t} \\
& =\lim _{\Delta t \rightarrow 0} \frac{F(t+\Delta t)-F(t)}{\Delta t S(t)}
\end{aligned}
$$

$=\frac{f(t)}{S(t)}$

The mathematical relationship between the functions $f(t), F(t), S(t)$ and $h(t)$ were given by Equation (9):

$$
h(t)=\frac{f(t)}{S(t)}=\frac{\left(\frac{d F}{d t}\right)}{S(t)}=\frac{\left[\frac{d(1-S)}{d t}\right]}{S(t)}=\frac{\left(-\frac{d S}{d t}\right)}{S(t)}=-d \ln S(t) / d t
$$

In addition to the period length, a group of descriptive variables that included both economic and non-economic variables might have some effect, so the duration distribution was modified by including other explanatory variables in SA. Therefore, the hazard function must be defined again and must be re-formulated to capture the uncertainty in these variables. Therefore, the new hazard function was given by Equation (10):

$$
h(t, x, \theta, \beta)=\lim _{\Delta \rightarrow 0} \frac{\operatorname{Pr}(t \leq T<t+\Delta \mid T \geq t)}{\Delta}
$$

Here, the unidentified factor vector $X$ was expressed with $\beta$, which was an explanatory variable that may comprise time-changing and time-constant variables, whereas the limitation vector $\theta$ illustrates the hazard rate function of the distribution. The hazard function $h(t, x, \theta, \beta)$ can be divided into two parts upon the addition of explanatory variables. The first factor included the hazard to be determined by the attributes of the subject $g(x, \beta)$. The benchmark hazard function $h_{o}(t)$ was the second factor and is equivalent to the hazard while all covariates are zero. Consequently, it did not rely on any individual qualities. This factor reflected the pattern of hazard rate changes over time.

The semi-parametric Cox hazard model was employed in order to evaluate the SA(COX, 1972). The semi-parametric Cox model has been extensively used to analyse survival data in order to determine the impact of descriptive variables on the hazard ratio. However, the semi-parametric model could be less effective than the parametric model in terms of utilization of material given by the data (D'EMDEN et al., 2006). In particular, efficiency could be very little (EFRON, 1977). Furthermore, when utilizing this model, the study was able to obtain robust results. In addition, the assessments of variable characterization 
were practical but with little consideration of the real state of the benchmark hazard function.

In this case, the benefit of a semi-parametric approach was that no presumptions were made about the state of the hazard estimation. According to the Cox-proportional hazard model, the period of every individual from the sample data was expected to have its own hazard estimation $h_{l}(t)$, which can be written as Equation (11):

$h_{i}(t)=h\left(t ; x_{i}\right)=h_{o}(t) \exp \left(x_{i} \beta\right)=h_{o}(t) \exp \left(\beta_{1} x_{1}+\cdots+\beta_{k} x_{i k}\right)$ (11)

Accordingly, the log form of Equation (11) was given by Equation (12): $\log h_{i}(t)=a(t)+\beta_{1} x_{i 1}+\cdots+\beta_{k} x_{i k}$

Where the benchmark hazard function $h_{o}(t)$ was self-assertive and unspecified and cannot be negative. Additionally, $a(t)=\log h_{o}(t)$. The coefficient $\beta$ was translated as a steady comparative impact of $x$ on the restrictive likelihood of finishing a period. It was the required attribute of the individual in the population that demonstrates the comparative hazard function such that the ratio $\frac{\text { hit }}{\text { hit }}=\exp \left[\beta_{1}\left(x_{i 1}-x_{j 1}\right)+\cdots+\beta_{k}\left(x_{i k}-x_{j k}\right)\right]$ of substances $i$ and $j$ were constant with time $t$, and so $h_{o}(t)$ with drawed.

COX (1972) introduced a method based on the partial probability function, which wiped out the obscure baseline hazard $h_{\mathrm{o}}(t)$. In this manner, the bit of the probability function that contains hazarddependent information promptly was eliminated. Likewise, this part of the function represents the censored time period. In view of the time period of every individual $i . t_{i}, i=1 \ldots n$, the partial $\log$ probability can be written as Equation (13):

$$
P P=\prod_{i=1}^{n}\left[\frac{e^{\beta x_{i}}}{\sum_{j=1}^{n} Y_{i j} e^{\beta x_{i}}}\right]^{\delta_{i}}
$$

Where the indicator variable is $\delta_{i}$; if $t_{i}$ was censored, the value of $\delta i$ will be zero. Otherwise, if $\mathrm{t}_{\mathrm{i}}$ was uncensored, the value $\delta_{i}$ will be one. Therefore, if $t_{j} \geq t_{i}$ then $Y_{i j}=1$ or if $t_{j}<t_{i}$ then $Y_{i j}=0$. The maximization problem to exploit the partial probability function could be written as Equation (14):

$$
\log P P=\max _{\beta} \sum_{i=1}^{n} \delta_{i}\left[\beta x_{i}-\log \left(\sum_{j=1}^{n} Y_{i j} e^{\beta x_{j}}\right)\right]
$$

\section{Empirical application}

This study was conducted using data collected from Toba Tek Singh, Khanewal, and Jhang, three of the central districts in the Pakistan province of Punjab (Figure 2) and played vital role in organic farming (AKRAM et al., 2019a). These specific districts were determined according to groups such as organic farmers, villagers, and growers and other principal stakeholders' following consultation. The organic farming project taking place in Lok Sanjh also informed this choice of districts. A stratified sampling technique was adopted to identify 400 farmers, both conventional and organic, across the three regions. The farmers' names were listed in alphabetical order and numbered. The stratified random sampling technique was adopted to select the sample household, to ensure that every household had an equivalent probability of being selected for the study, irrespective of farm size. As a means of closely identifying conventional farmers, proximity was defined as the fundamental criteria. The final dataset comprised information obtained from 148 organic farmers and 153 conventional farmers. A farm household leader survey was performed to collect data during the period September 2018-February 2019 in cooperation with the Lok Sanjh Foundation. A questionnaire was developed to acquire data regarding farm structure and management, family characteristics, farmer's opinions and practices, and input and output data.

Comprehensive data on farmer's personal attributes, opinion and approach, farm's economic and physical aspects, and other factors influencing the decision to adopt organic methods were collected. Data gathered about the family and personal attributes of the farmer $\left(P_{i}\right)$ included age, marital status, number of schooling years, farmer or family member with a university degree, members of the family, or closeness of family, and companions to the farmer's home. Data on the structural management of the farm $\left(S_{i}\right)$ comprised the size of the farmland, land tenure arrangements (The study area includes three kinds of farmland arrangements i.e. ownership, fixed rent, and sharecropper), and type of soil, farm mechanization, and farm distance from farmer's house, location of the farm, and accessibility to the market. The factors that reflected the farm operational management $\left(M_{i}\right)$ were the cultivation method adopted, crop rotation, analysis of soil, input use, external labour, availability of family labour, irrigation source, power source, per hectare cost, profitability, and the share of farm income out of the total income of the family. The influence of external variables $\left(E_{i}\right)$ consisted of information source and accessibility to the Internet, being a member of any agricultural organization, size of the market, government policies, subsidies, input cost, output prices, conversion cost, and availability of financial aid such as loans or other supportive projects.

Information about the farmer's opinion and approach $\left(O_{i}\right)$ regarding organic farming was collected by asking the farmers a series of questions based on a Like rt scale ( 0 to 10$)$. These questions involved organic farming, environmental issues, 


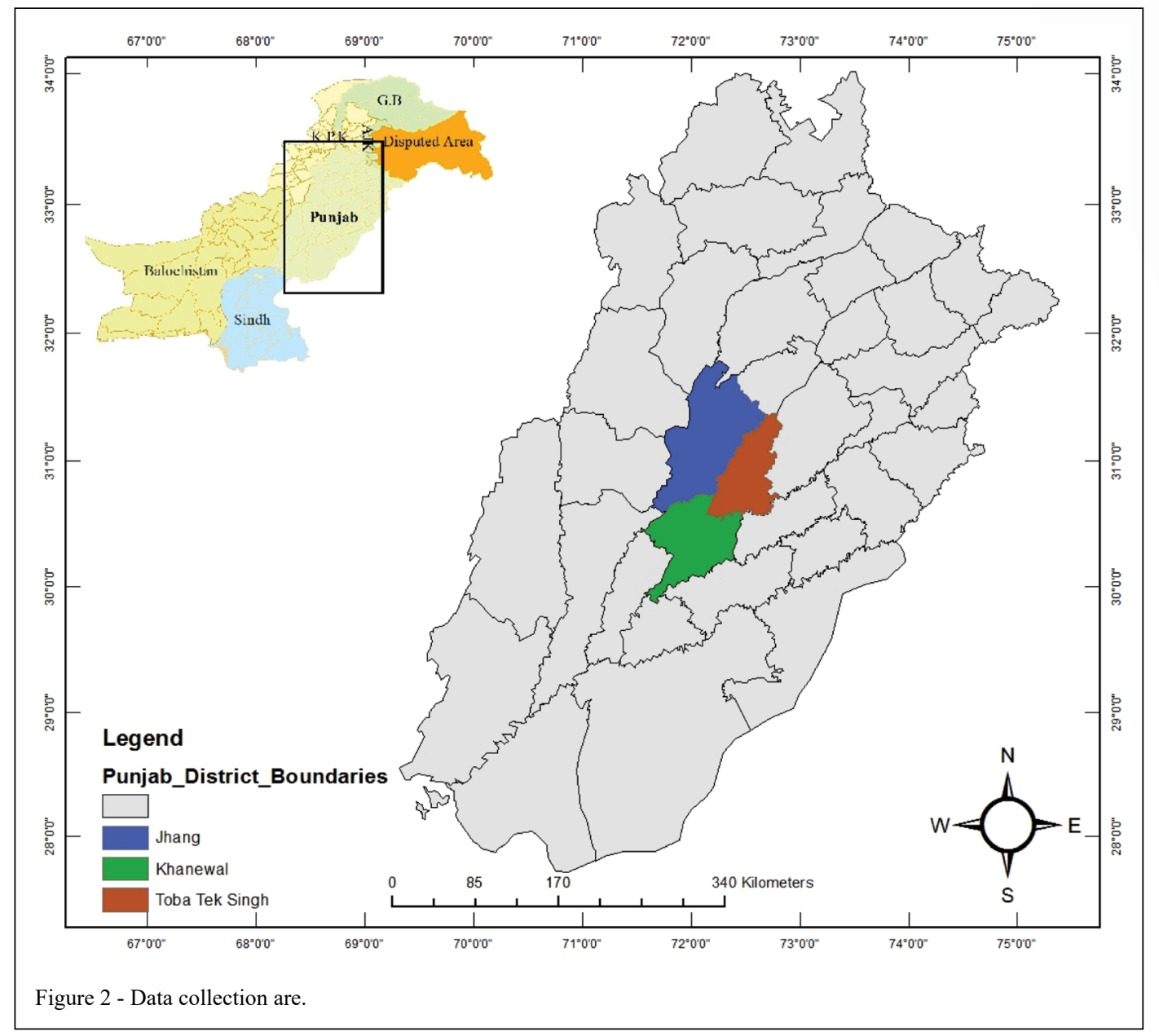

approach towards risk, utilization of chemical or hazardous inputs, governance of problems, economic agent's opinion about organic approach, benefits to the farmer when changing over, and other queries. Broad data on this issue was accumulated, so, as mentioned earlier, the accessible data was summarized to narrow down the measurements using PCA. The subsequent components as an independent variable were utilized in a successive phase in SA.

Data about the farmers' goals $\left(G_{i}\right)$ (The primary and secondary goals were divided into two distinct priorities: the first was combined by an agroeconomics faculty in a university, and the second was explained by the staff of organizations working for organic farming), was gathered by probing farmers to use a scale of 1 to 9 to compare different goals in paired form. dummy variable was also employed by taking a value of 1 after the year 2008 to indicate the year in which the National Institute of Organic Agriculture was established (otherwise, a value of zero was used) (BURTON et al., 2003).
KIEFER (1988) stated that SAneeds an exact start time to calculate duration. In this study's scenario, time was designated as the date by which the farmer began to oversee holding ALLISON (1995) provided a simple answer to solve the random censor issue, which is to use the covariate of time of entry in the regression.

\section{RESULTS AND DISCUSSION}

The data of numerous variables were collected in order to evaluate the opinion and approach of the farmer in which PCA was used in three steps. Initially, PCA was employed for the variables that evaluated the farmers' perceptions of society's attitudes regarding organic agriculture. The pertinent components of this variable were "Commercial prospects"(C1) and "Social prospects" (C2) (Table $3)$. The subsequent PCA was used to determine the motivation of the farmer to adopt organic farming. The resulting components were "Domestic and foreign aspects" (C3), "Financial incentive" (C4) and "Personal 
Table 3 - Principal Component Analysis of Farmer's opinion and approach.

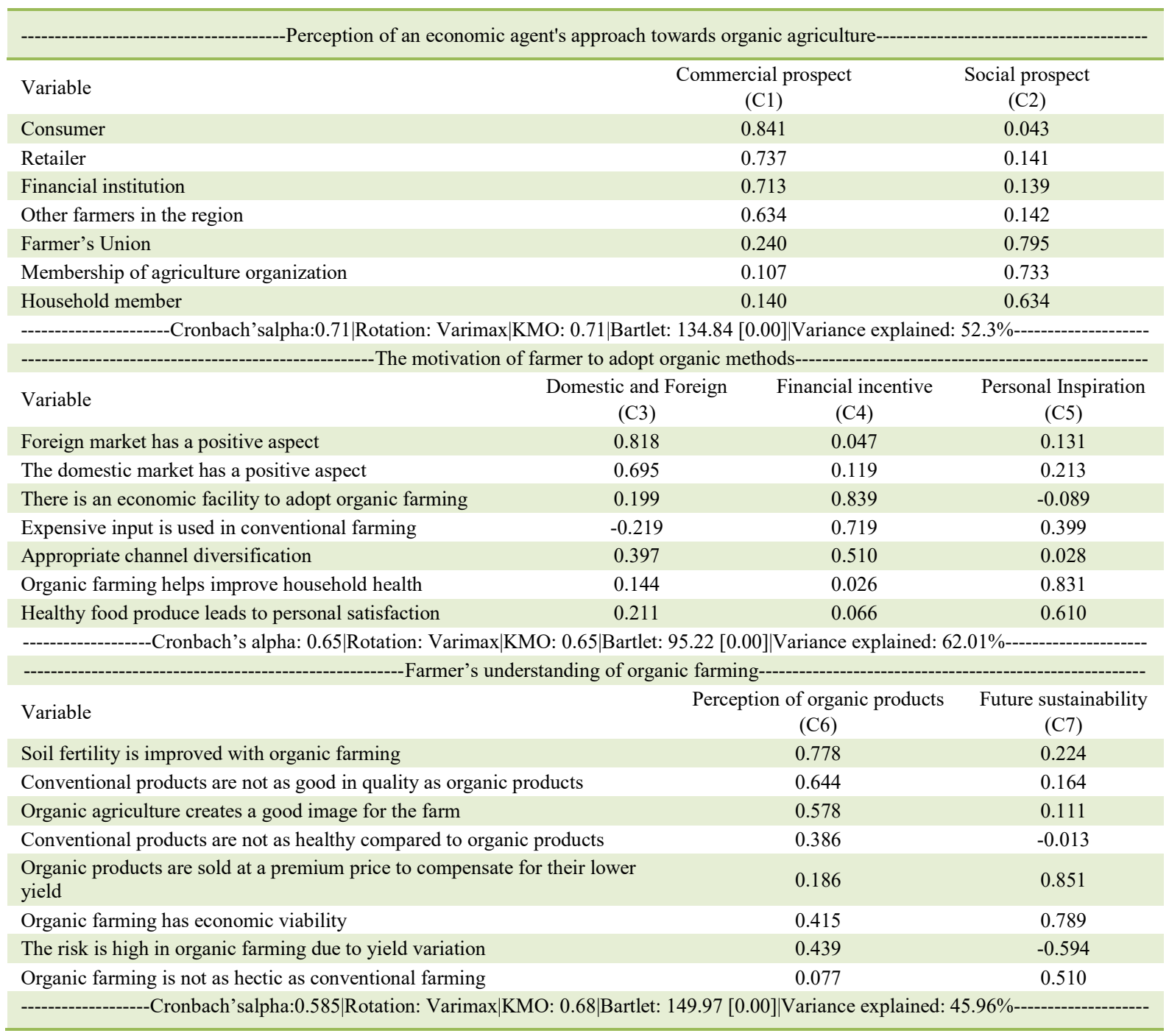

inspiration" (C5). The last PCA was employed to determine the farmers' personal understanding of organic agriculture concerning "Organic product" (C6) and "Future sustainability" (C7).

As mentioned above, AHP permitted the use of geometric mean to assign weights to the primary and secondary goal of every individual (farmer). Table 4 listed the weighted summary results for the farmers' three primary goals, which indicated that the financial goal (WG1) was a top priority, while environmental (WG2) and social goals (WG3) were on the second and third priorities with aggregated weights of $78.40 \%, 13.80 \%$, and $7.80 \%$, respectively, for conventional farmers. This order applied to the organic category as well, but environmental and social goals were more closely related rather than an economic goal.

Figure 3 showed the weighted outcome of the secondary goals. As observed, conventional and organic farmers have different comparative weights. It's important to point out that organic farmers gave more attention to encouraging environmentally sound practices, while conventional farmers care more about water and quality of the soil. The comparative weight proportions for the primary and secondary goals of every farmer were summarized in table 5 . As stated above, these goal proportions were later used as covariates in the SA.

Different SA models were assessed using different variable combinations obtained from the 
Table 4 - Aggregated weights of the farmer's goal (Conventional \&Organic).

\begin{tabular}{|c|c|c|c|c|c|c|}
\hline & \multicolumn{2}{|c|}{-------Financial Goal $\left(\mathrm{WG}_{1}\right)$------- } & \multicolumn{2}{|c|}{----Environmental Goal $\left(\mathrm{WG}_{2}\right)$----- } & \multicolumn{2}{|c|}{------Social Goal $\left(\mathrm{WG}_{3}\right)$------ } \\
\hline & Conventional & Organic & Conventional & Organic & Conventional & Organic \\
\hline $\begin{array}{l}\text { Geometric mean } \\
\text { (Aggregate weight) }\end{array}$ & 0.784 & 0.457 & 0.138 & 0.371 & 0.078 & 0.172 \\
\hline Arithmetic mean & 0.741 & 0.445 & 0.139 & 0.364 & 0.120 & 0.191 \\
\hline Trimmed mean ${ }^{*}$ & 0.819 & 0.356 & 0.117 & 0.316 & 0.064 & 0.169 \\
\hline Variance & 0.054 & 0.031 & 0.010 & 0.021 & 0.013 & 0.012 \\
\hline Median & 0.810 & 0.446 & 0.143 & 0.318 & 0.061 & 0.159 \\
\hline
\end{tabular}

${ }^{*}$ Calculated by discarding the $25 \%$ highest and lowest values.

survey. A stepwise forward technique was used for the final variable list in the SA estimation. It means the selection criteria consist of three methods i.e. forward, backward, and bidirectional eliminating methods. This selection criterion was first proposed by EFROYMSON (1960). Table 6 showed the list of all variables for organic and conventional farmers included in the SA model. The model estimation results were shown in table 7 , where the null hypothesis (all coefficients are mutually equal to zero) was rejected at $5 \%$ level of significance.

The existence of local officials was considered as information sources, and this led to the escalation of the hazard function, which includes reducing the necessary time to adapt. This finding was in agreement with the results of (RIGBY et al., 2001) and (LÓPEZ \& REQUENA, 2005), which explained that the source of information accessibility was a highly essential component in determining adaptation.
Results also showed that farmers that were inclined towards risk were more likely to adopt organic agriculture. DE COCK (2005) confirmed this result, indicating that organic farmers usually have less care of risk than conventional farmers. SERRA et al. (2008) also reported similar findings that organic farmers were prone to taking risk than their conventional counterparts. The current study also reported that a problem in receiving loans increased the farmers' conversion to organic farming. This was because organic farmers generally belong to smallerscale farms that faced more problems accessing loan facilities which lead them to convert organic farm due to their low ability to afford higher input cost compared to conventional farmers. This result opposed the argument credit limit decreasing conversion rate finding of RIGBY et al. (2001) and LAMKIN (1994), which explained that the essential institution obstacles to

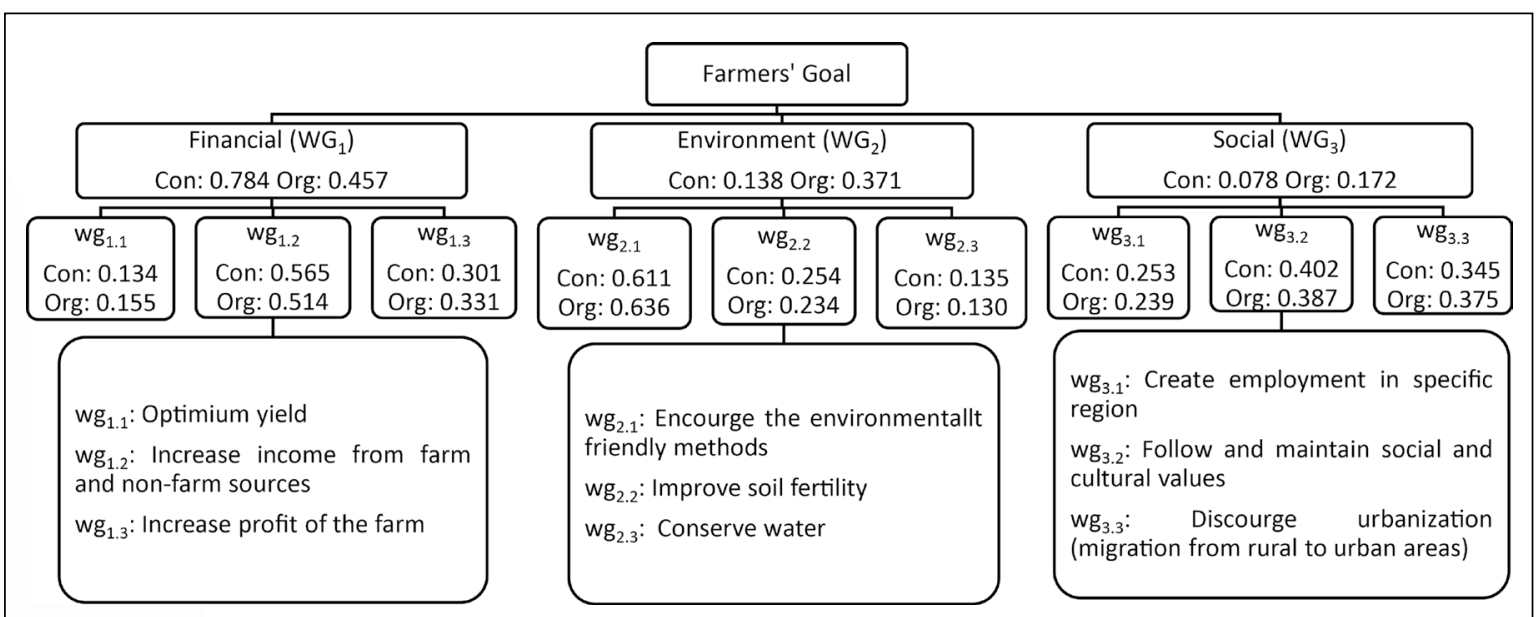

Figure 3 - Farmers' goal weights. 
Table 5 - Comparative weights of primary and secondary goals included in SA.

\begin{tabular}{|c|c|c|c|c|c|}
\hline \multirow[t]{2}{*}{ Variable } & \multirow[t]{2}{*}{ Description } & \multicolumn{2}{|c|}{-------Organic----- } & \multicolumn{2}{|c|}{-----Conventional--- } \\
\hline & & Mean & Std. dev. & Mean & Std. dev. \\
\hline $\mathrm{WG}_{2} / \mathrm{WG}_{1}$ & Comparative weight between "Environmental and Financial" goals & 4.71 & 5.36 & 9.63 & 10.36 \\
\hline $\mathrm{WG}_{1} / \mathrm{WG}_{3}$ & Comparative weight between "Financial and Social" goals & 0.89 & 1.09 & 4.41 & 19.49 \\
\hline $\mathrm{WG}_{2} / \mathrm{WG}_{3}$ & Comparative weight between "Environmental and Social" goals & 0.24 & 0.10 & 0.13 & 0.34 \\
\hline $\mathrm{Wg}_{1.1} / \mathrm{Wg}_{1.2}$ & $\begin{array}{c}\text { Comparative weight between "Optimum yield and Increase farm \& non- } \\
\text { farm income" }\end{array}$ & 0.92 & 0.95 & 0.75 & 1.43 \\
\hline $\mathrm{Wg}_{1.1} / \mathrm{Wg}_{1.3}$ & Comparative weight between "Optimum yield and Farm profit" & 0.48 & 0.58 & 0.94 & 3.11 \\
\hline $\mathrm{Wg}_{1.2} / \mathrm{Wg}_{1.3}$ & $\begin{array}{c}\text { Comparative weight between "Increase farm \& non-farm income and Farm } \\
\text { profit" }\end{array}$ & 2.74 & 2.49 & 2.99 & 2.44 \\
\hline $\mathrm{Wg}_{2.1} / \mathrm{Wg}_{2.2}$ & $\begin{array}{c}\text { Comparative weight between "Encourage environmentally friendly methods } \\
\text { and Improve soil fertility." }\end{array}$ & 1.76 & 2.68 & 1.93 & 4.08 \\
\hline $\mathrm{Wg}_{2.1} / \mathrm{Wg}_{2.3}$ & $\begin{array}{c}\text { Comparative weight between "Encourage environmentally friendly methods } \\
\text { and Conserve water" }\end{array}$ & 1.01 & 0.96 & 1.08 & 1.71 \\
\hline $\mathrm{Wg}_{2.2} / \mathrm{Wg}_{2.3}$ & Comparative weight between "Improve soil fertility and Conserve water " & 1.67 & 2.33 & 1.96 & 2.20 \\
\hline $\mathrm{Wg}_{3.1} / \mathrm{Wg}_{3.2}$ & $\begin{array}{l}\text { Comparative weight between "Create employment opportunities in the } \\
\text { specific region and Follow and maintain social and cultural values." }\end{array}$ & 3.83 & 2.60 & 3.30 & 3.59 \\
\hline $\mathrm{Wg}_{3.1} / \mathrm{Wg}_{3.3}$ & $\begin{array}{l}\text { Comparative weight between "Create employment opportunities in the } \\
\text { specific region and Discourage the urbanization (migration from rural to } \\
\text { urban areas)" }\end{array}$ & 6.90 & 5.99 & 4.27 & 4.33 \\
\hline $\mathrm{Wg}_{3.2} / \mathrm{Wg}_{3.3}$ & $\begin{array}{c}\text { Comparative weight between "Follow and maintain the social and cultural } \\
\text { values and Discourage the urbanization (migration from rural to urban } \\
\text { areas)" }\end{array}$ & 2.45 & 2.14 & 2.71 & 3.45 \\
\hline
\end{tabular}

organic farming conversion were the denial of loans and insurance to the farmer.

As anticipated, it was reported that farms with no canal irrigation facility were more prone to adopting organic farming compared to their counterparts. The reason behind this phenomenon was the irrigation cost in that area, so the yield was lower than other areas, as described in other studies (NEERA et al., 1999; MARTINI et al., 2004; VALIZADEH et al., 2014). These studies explained that productivity varied according to region. It was difficult for small farmers to afford higher input cost to obtain higher yield in conventional farming, so they focused on organic farming to reduce input cost. Farmers with other sources of income apart from farm income will probably have more chances to adopt organic farming. This finding was backed by that of Peters (1994) and (HANSON et al., 2004), which explained that diversification in the source could play a vital role in pushing farmers to adopt organic farming compared to farmers with only a single source of income (from the farm). These outcomes were in line with the statement that organic farmers often engaged in different kinds of activities, which diminish the hazard from conceivable yield misfortunes. Farmers whose choices were assumed dependent on business reasons were found to engage in lower risk.
The finding of past studies also showed that the positive behaviour and attitude of the farmer towards organic agriculture resulted in a short time to convert. The individuals that have faith and a positive view of social operator's inorganic farming concur that unsafe synthetic inputs toward humans should be banned and perceived organic items as being healthier than non-organic items. These people have more tendency to change over. RIGBY et al. (2001) and DARNHOFER et al. (2005) also explained that positive behaviour and attitude led to a positive impact on the decision to convert.

The finding of this study showed that young farmers tend to adopt organic farming compared to older ones quickly. RIGBY et al. (2001) and ANDERSON et al. (2005) also reported similar findings. Farmers that were in-charge of farm management were also harder to convert. Past studies also revealed similar findings (BURTON et al., 1999; HATTAM \& HOLLOWAY, 2005; HUSNAIN et al., 2017), where organic farmers' land holding was smaller than that of conventional farmers. Therefore, big farmland will take more time to adopt organic farming due to a low hazard.

The dummy variable (before and after 2008) was added to assess the impact of the "National Institute of Organic Agriculture in Pakistan" on the 
Table 6 - Variable include in SA model.

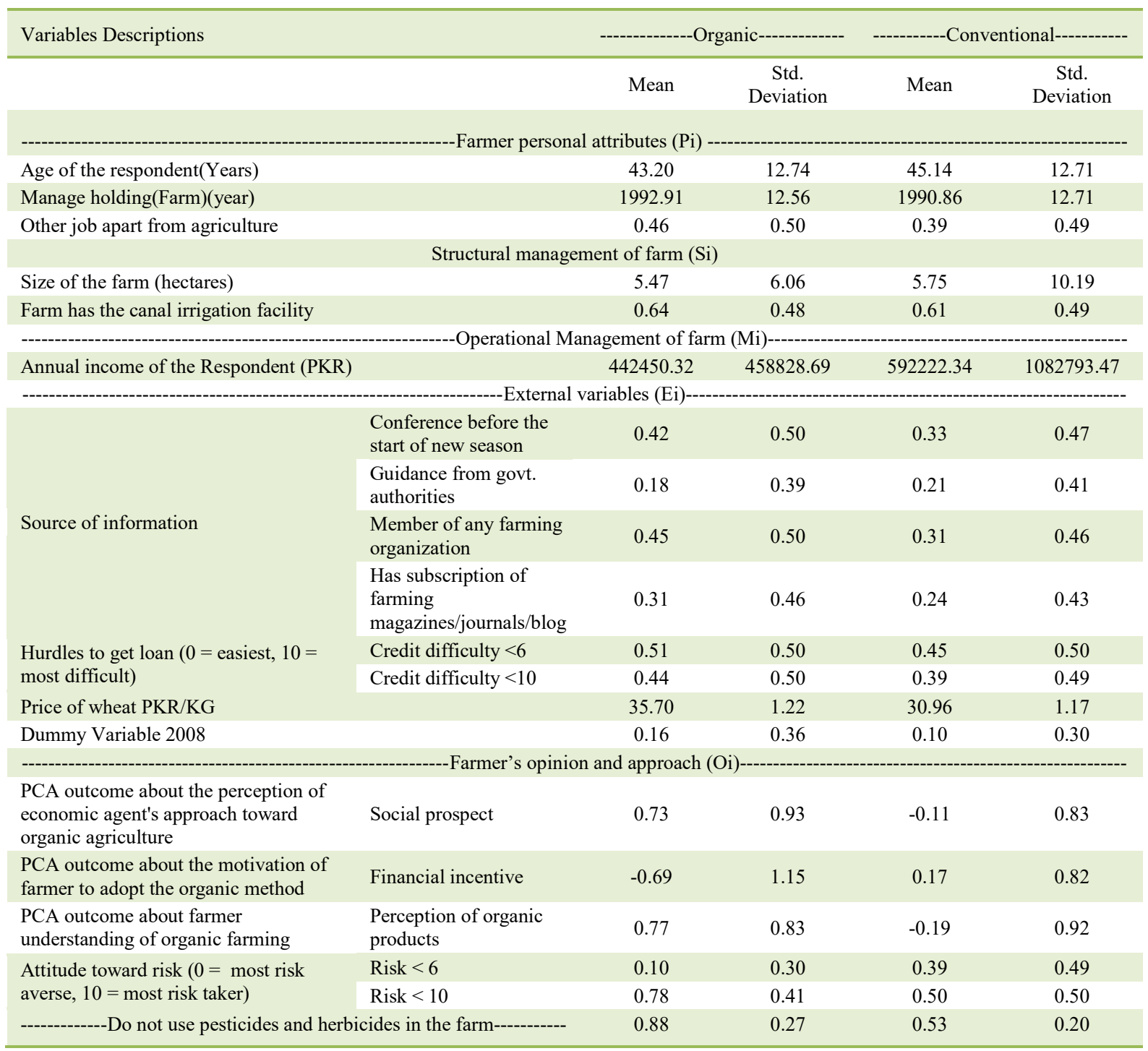

decision to adopt organic farming. This variable was statistically insignificant, but it still had a positive impact overall. Result showed that the establishment of the institute encouraged organic farming, but its role to promote organic farming has not been enough.

The finding in this study showed that the significance of the environment was a more essential component than the financial aspect when choosing organic practices. Therefore, increasing the weight of the environmental goal compared to the weight of the financial goal will lead to an increased hazard. In addition, a weight increased in the farmer's opinion to practice "environmentally friendly methods" compared to "conserving water" will reduce the duration to adopt. At the same time, the goal of "creating employment opportunities in specific regions" was inevitable to "discourage urbanization" and thus increasing the possibility of transformation in a shorter period. These outcomes showed that both the dedication of the organic farmer to protecting the environment and employment generation were essential elements to change. Prior empirical studies suggested that organic farming was considered a particularly labour-intensive method of farming (DEMIRYUREK and CEYHAN, 2008). According to this argument, this study showed that creating 
Table 7 - Survival analysis (Cox-proportional hazard model using partial likelihood).

\begin{tabular}{|c|c|c|c|}
\hline Variable & Parameter & Standard error & Hazard Ratio \\
\hline Comparative weight between "Environmental and Financial" goals & $0.734^{* *}$ & 0.335 & 2.147 \\
\hline $\begin{array}{l}\text { Comparative weight between "Encourage environmentally friendly methods and } \\
\text { Conserve water." }\end{array}$ & $0.246^{* * *}$ & 0.132 & 1.313 \\
\hline $\begin{array}{l}\text { Comparative weight between "Creating employment opportunities in the } \\
\text { specific region and Discouraging urbanization (migration from rural to urban } \\
\text { areas)" }\end{array}$ & $0.741^{* * *}$ & 0.251 & 2.041 \\
\hline Age of respondent & $-0.342^{* * *}$ & 0.131 & 0.836 \\
\hline Manage holding(Farm) & $0.135^{* *}$ & 0.130 & 1.140 \\
\hline Other job apart from agriculture $(0=\mathrm{No}, 1=$ Yes $)$ & $2.604^{* *}$ & 1.015 & 13.261 \\
\hline Annual income of respondent & $0.031^{*}$ & 0.024 & 1.416 \\
\hline Size of farm & $-0.104^{* * *}$ & 0.106 & 1.024 \\
\hline Farm has a canal irrigation facility $(0=$ No, $1=$ Yes $)$ & $2.015^{* *}$ & 0.684 & 4.631 \\
\hline Guidance from Govt. authorities $(0=$ No, $1=$ Yes $)$ & $4.338^{* * *}$ & 1.428 & 86.041 \\
\hline Credit difficulty $(0<6,1>5)$ & $2.324^{* * *}$ & 0.756 & 10.134 \\
\hline Price of wheat & $1.002^{* *}$ & 0.401 & 2.517 \\
\hline Dummy variable $2008(0=$ before $2008,1=$ after 2008$)$ & 4.317 & 1.614 & 74.153 \\
\hline Risk $(0<6,1>5)$ & $2.147^{* *}$ & 0.942 & 10.247 \\
\hline Does not use pesticides or herbicides in the farm $(0<6,1>5)$ & $1.957^{* * *}$ & 0.785 & 10.235 \\
\hline $\begin{array}{l}\text { PCA outcome about the perception of an economic agent's approach towards } \\
\text { organic agriculture }\end{array}$ & $1.324^{* *}$ & 0.510 & 2.978 \\
\hline PCA outcome about motivation of farmer to adopt organic method & $-1.525^{* * *}$ & 0.550 & 0.159 \\
\hline PCA outcome about farmer's understanding of organic farming & $1.487^{* * *}$ & 0.491 & 3.992 \\
\hline
\end{tabular}

Likelihood ratio: 135.126(0.000)/Wald test: 34.345(0.004)/Larange multiplier: $94.735(0.000)$.

employment opportunities was an essential element for farmers to adopt organic farming; further highlighting the social role of organic farming in Pakistan.

\section{CONCLUSION}

This study emphasized the assessment of time to adopt organic farming and the farmers' decisions to convert. A Survival Analysis (SA) was performed for the empirical analysis because it enabled the analysis of decision-making and diffusion characteristics of organic farming. The model was used to evaluate utilizing farm-level information from organic and conventional farmers in Punjab, Pakistan. A survey was performed to collect data during the period of September 2017-February 2018.

The waiting time of the farmer to adopt organic farming was used as a dependent variable in SA. This variable was measured based on the time period of the farmer to start managing the farm in several years. Different explanatory variables were taken into account to signify the farmer's personal attributes, structural management of the farm, operational management of the farm, external variables, the farmer's opinion and approach, and the farmer's goal and intentions. AHP was used to evaluate the goal where as PCA was used to surmise the opinions and approaches of the farmers.

Many variables were discovered to increase the chances of conversion. Farmers who had started to manage farms in recent years, farmers that did not paid much attention to risk, farmers that wanted to protect the environment, and farmers that wanted to create jobs in their farm tend to adopt organic farming in a shorter duration of time. Farmers that did not have a canal irrigation facility and farmers that have other sources of income apart from agriculture also have higher chances of adopting organic farming. Farmers that get a higher price for their products, farmers that experience issues obtaining loans, and farmers that have other sources of income apart from farming were also more prone to choose organic farming. Finally, the availability of information and guidance from government experts pertaining to policies and guidelines have led to higher acceptance rates. Then again, more established farmers whose choices were basically dependent on financial factors and who were running exceptionally specific and large 
farms, have a low probability of adopting organic farming. Inclusively, the outcomes were effective collectively, as they suggested that small scale farmer easy to adopt organic farming or those have small land and participate to other kind of business or job. Large scale farmer or who purely depended on agriculture took more time. Mostly farmer were lay man and they did not have concern to other factors like environment or society, only focused on financial benefit. Study suggested that Government should regulate and market the authentic organic products. Hence, more formal and collective effort required to promote organic farming

This empirical analysis was performed using a semi-parametric methodology; and therefore, still required parameterization of the hazard work. Miss-specification of this model could lead to conflicting outcomes. The outcomes of this study needed to be deciphered cautiously. In order to overcome this constraint, the literature has recently introduced local assessment techniques. Therefore, it was recommended that the findings of this study could be compared to future research employing this alternative method.

\section{ACKNOWLEDGEMENTS}

We would like to acknowledge the Lok Sanjh Foundation Pakistan, for providing technical data related to this study.

\section{FUNDING}

Ilma University Karachi Pakistan and Northeast Forestry University Harbin China.

\section{DECLARATION OF CONFLICT OF INTERESTS}

We have no conflict of interest to declare.

\section{REFERENCES}

ACS, S. et al. Conversion to organic arable farming in The Netherlands: Adynamic linear programming analysis. Agricultural Systems, 94(2), 405-415, 2007.

AGUARÓN, J.; MORENO-JIMÉNEZ, J. M. A. Local stability intervals in the analytic hierarchy process. European journal of operational research, 125(1), 113-132, 2000

AKRAM, M. W. et al. Impact of Land Use Rights on the Investment and Efficiency of Organic Farming. Sustainability, 11(24), 7148, 2019a.

AKRAM, M. W. et al. An assessment of economic viability of organic farming in Pakistan. Custos e Agronegocio Online, 15(1), 141$169,2019 b$.
AKRAM, M. W. et al. Socioeconomics Determinants to Adopt Agricultural Machinery for Sustainable Organic Farming in Pakistan: A Multinomial Probit Model. Sustainability, 12(23), 9806, 2020 .

ALLISON, D. R. When is it worth measuring a covariate in a randomized clinical trial? Journal of consulting and clinical psychology, 63(3), 339, 1995

ANDERSON, J. B. et al. Determinants of farmer adoption of organic production methods in the fresh-market produce sector in California: A logistic regression analysis. Paper presented at the 2005 Annual Meeting, July 6-8, 2005.

AUERBACH, R. Transforming african agriculture: Organics and agra. Organic agriculture: african experiences in resilience and sustainability. 2013

BAKER, B. P.; MOHLER, C. L. Weed management by upstate New York organic farmers: Strategies, techniques and research priorities. Renewable agriculture and food systems, 30(5), 418-427. 2015

BAUMANN, M. J. et al. Structural evidence for the evolution of xyloglucanase activity from xyloglucan endo-transglycosylases: biological implications for cell wall metabolism. The Plant Cell, 19(6), 1947-1963, 2007.

BOX-STEFFENSMEIER, J. M.; ZORN, C. Duration models for repeated events. Journal of Politics, 64(4), 1069-1094, 2002.

BRYSON, J. W. et al. Protein design: a hierarchic approach. Science, 270(5238), 935-941, 1995.

BURTON, M. et al. Analysis of the determinants of adoption of organic horticultural techniques in the UK. Journal of Agricultural Economics, 50(1), 47-63, 1999.

BURTON, M. et al. Modelling the adoption of organic horticultural technology in the UK using duration analysis. Australian Journal of Agricultural and Resource Economics, 47(1), 29-54, 2003.

CALATRAVA-REQUENA, J.; GONZÁLEZ, M. Technical versus institutional innovation in Andalusian olive tree orchards: an adoption modelling analysis. Paper presented at the 12th Congress of the European Association of Agricultural Economists. Gent, Belgium, 2008.

COX, D. R. Regression models and life-tables. Journal of the Royal Statistical Society: Series B (Methodological), 34(2), 187-202, 1972.

D'EMDEN, F. H. et al. Adoption of conservation tillage in Australian cropping regions: an application of duration analysis. Technological forecasting and social change, 73(6), 630-647, 2006.

DADI, L., et al. Duration analysis of technological adoption in Ethiopian agriculture. Journal of Agricultural Economics, 55(3), 613-631, 2004.

DARNHOFER, I. et al. Converting or not converting to organic farming in Austria: Farmer types and their rationale. Agriculture and human values, 22(1), 39-52, 2005.

DE COCK, L. Determinants of Organic Farming Conversion. Paper presented at the International Congress, August 23-27, 2005 , , Copenhagen, Denmark, 2005. 
DE SOUZA FILHO, H. et al. Factors influencing the adoption of sustainable agricultural technologies: evidence from the State of Espírito Santo, Brazil. Technological forecasting and social change, 60(2), 97-112, 1999.

DEMIRYUREK, K.; CEYHAN, V. Economics of organic and conventional hazelnut production in the Terme district of Samsun, Turkey. Renewable agriculture and food systems, 23(3), 217227, 2008.

EASLEY, M. E. et al. Isolated subtalar arthrodesis. JBJS, 82(5), 613,2000

EFRON, B. The efficiency of Cox's likelihood function for censored data. Journal of the American statistical Association, 72(359), 557-565, 1977.

EFROYMSON, M. Multiple regression analysis. Mathematical methods for digital computers, 191-203, 1960.

FEDER, G.; UMALI, D. L. The adoption of agricultural innovations: a review. Technological forecasting and social change, 43(3-4), 215-239, 1993.

FICHTNER, J. On deriving priority vectors from matrices of pairwise comparisons. Socio-Economic Planning Sciences, 20(6), 341-345, 1986.

FORMAN, E., \& PENIWATI, K. Aggregating individual judgments and priorities with the analytic hierarchy process. European journal of operational research, 108(1), 165-169, 1998.

FROEHLICH, A. G. et al. Comparing the Profitability of Organic and Conventional Production in Family Farming: Empirical Evidence From Brazil. Ecological Economics, 150, 307-314, 2018.

GARDEBROEK, C. Comparing risk attitudes of organic and nonorganic farmers with a Bayesian random coefficient model. European Review of Agricultural Economics, 33(4), 485-510, 2006.

GARDEBROEK, C.; JONGENEEL, R. The growth in organic agriculture: temporary shift or structural change. Paper presented at the Annual Meeting of the American Agricultural Economics Association, Denver, USA, 2004.

GENIUS, M. et al. Information acquisition and adoption of organic farming practices. Journal of Agricultural and Resource economics, 93-113, 2006.

GODFRAY, H. C. J. et al. Food security: the challenge of feeding 9 billion people. Science, 327(5967), 812-818, 2010.

HANSON, J., et al. Risk and risk management in organic agriculture: Views of organic farmers. Renewable agriculture and food systems, 19(4), 218-227, 2004.

HATTAM, C. E.; HOLlOWAY, G. J. Adoption of certified organic production: evidence from Mexico. 2005.

HUSNAIN, M. et al. An assessment of public and private benefits of organic farming in Pakistan. JAPS: Journal of Animal \& Plant Sciences, 27(3), 2017.

ISIN, F. et al. Factors affecting the adoption of the organic dried fig agriculture system in Turkey. Journal of applied sciences, 7, 748-754, 2007
KAFLE, B. Factors affecting adoption of organic vegetable farming in Chitwan District. Nepal. 2011.

KAUFMANN, P. et al. Simulating the diffusion of organic farming practices in two New EU Member States. Ecological Economics, 68(10), 2580-2593, 2009.

KERSELAERS, E. et al. Modelling farm-level economic potential for conversion to organic farming. Agricultural Systems, 94(3), 671-682, 2007.

KIEFER, N. M. Economic duration data and hazard functions. Journal of economic literature, 26(2), 646-679, 1988.

KLEEMANN, L. et al. Certification and access to export markets: Adoption and return on investment of organic-certified pineapple farming in Ghana. World Development, 64, 79-92, 2014.

KNOLL, F. J. et al. Improving efficiency of organic farming by using a deep learning classification approach. Computers and electronics in agriculture, 153, 347-356, 2018.

KNOWLER, D.; BRADSHAW, B. Farmers' adoption of conservation agriculture: A review and synthesis of recent research. Food policy, 32(1), 25-48, 2007.

KOESLING, M. et al. Factors influencing the conversion to organic farming in Norway. International Journal of Agricultural Resources, Governance and Ecology, 7(1-2), 78-95, 2008.

KUMINOFF, N. V.; WOSSINK, A. Valuing the option to convert from conventional to organic farming. Paper presented at the AAEA Annual Meeting, Providence, 2005.

KUMINOFF, N. V.; WOSSINK, A. Why isn't more US farmland organic? Journal of Agricultural Economics, 61(2), 240-258, 2010.

LAININEN, P., \& HÄMÄLÄINEN, R. P. Analyzing AHP-matrices by regression. European journal of operational research, 148(3), 514-524, 2003.

LAMKIN, N. The economic of organic farming an international perspective: Cab International. 1994.

LANCASTER, T. The econometric analysis of transition data: Cambridge university press. 1992.

LÄPPLE, D.; KELLEY, H. (2014). Spatial dependence in the adoption of organic drystock farming in Ireland. European Review of Agricultural Economics, 42(2), 315-337, 2014.

LÓPEZ, C. P.; REQUENA, J. C. Factors related to the adoption of organic farming in Spanish olive orchards. Spanish Journal of Agricultural Research, 3(1), 5-16, 2005.

MALA, Z.; MALY, M. The determinants of adopting organic farming practices: a case study in the Czech Republic. Agricultural Economics/Zemedelska Ekonomika, 59(1), 2013.

MARTINI, N. et al. Biological activity of five antibacterial flavonoids from Combretum erythrophyllum (Combretaceae). Journal of ethnopharmacology, 93(2-3), 207-212, 2004.

MCWILLIAMS, B.; ZILBERMANFR, D. Time of technology adoption and learning by using. Economics of Innovation and New technology, 4(2), 139-154, 1996. 
MEIER, M. S. et al. Environmental impacts of organic and conventional agricultural products-are the differences captured by life cycle assessment? Journal of Environmental Management, 149, 193-208, 2015.

MUSSHOFF, O.; HIRSCHAUER, N. Adoption of organic farming in Germany and Austria: an integrative dynamic investment perspective. Agricultural Economics, 39(1), 135-145, 2008.

MZOUGHI, N. Farmers adoption of integrated crop protection and organic farming: Do moral and social concerns matter? Ecological Economics, 70(8), 1536-1545, 2011

NEERA, P. et al. Comparison of rice yield after various years of cultivation by natural farming. Plant production science, 2(1), $58-64,1999$.

NIEMEYER, K.; LOMBARD, J. Identifying problems and potential of the conversion to organic farming in South Africa Paper presented at the Meeting of the Agricultural Economic Association of South Africa (AEASA), Pretoria, South Africa. 2003.

PADEL, S.; LAMPKIN, N. H. Conversion to organic farming: an overview. The economics of organic farming: An international perspective, 295-313, 1994.

PETERS, S. E. Conversion to low-input farming systems in Pennsylvania, USA: An evaluation of the Rodale farming system trial and related economic studies. The Economics of Organic Farming. CAB International, Wallingford, UK, $265-$ 284, 1994.

REGANOLD, J. P.; WACHTER, J. M. Organic agriculture in the twenty-first century. Nature plants, 2(2), 15221, 2016.

RIGBY, D. et al. The development of and prospects for organic farming in the UK. Food policy, 26(6), 599-613, 2001.

SAATY, T. L. A scaling method for priorities in hierarchical structures. Journal of mathematical psychology, 15(3), 234$281,1977$.
SAATY, T. L. The Analytic Hierarchy Process, McGraw HillInc, New York. 1980.

SARKER, M. et al. Determinants of adoption decisions: The case of organic farming (OF) in Bangladesh. Extension Farming Systems Journal, 5(2), 39, 2009.

SCHRAMA, M. et al. Crop yield gap and stability in organic and conventional farming systems. Agriculture, Ecosystems \& Environment, 256, 123-130, 2018.

SERRA, T., et al. Differential uncertainties and risk attitudes between conventional and organic producers: the case of Spanish arable crop farmers. Agricultural Economics, 39(2), 219-229, 2008.

SGROI, F. et al. Economic and financial comparison between organic and conventional farming in Sicilian lemon orchards. Sustainability, 7(1), 947-961, 2015.

STEELE, F. Multilevel models for longitudinal data. Journal of the Royal Statistical Society: series A (statistics in society), 171(1), 5-19, 2008

THAPA, G. B.; RATTANASUTEERAKUL, K. Adoption and extent of organic vegetable farming in Mahasarakham province, Thailand. Applied Geography, 31(1), 201-209, 2011.

ULLAH, A. et al. Factors affecting the adoption of organic farming in Peshawar-Pakistan. Agricultural Sciences, 6(06), 587, 2015.

VALIZADEH, J. et al. Assessing climate change impacts on wheat production (a case study). Journal of the Saudi Society of Agricultural Sciences, 13(2), 107-115, 2014.

WILLER, H.; LERNOUD, J. The world of organic agriculture. Statistics and emerging trends 2016: Research Institute of Organic Agriculture FiBL and IFOAM Organics International. 2016.

WILLER, H.; LERNOUD, J. The world of organic agriculture. Statistics and emerging trends 2018: Research Institute of Organic Agriculture FiBL and IFOAM Organics International. 2019. 